\section{$\nabla$ \\ Children's Alliance of New Hampshire}

Raising Our Voices for Children

SPRING 2010

\title{
Indicators of New Hampshire Youth Well-Being
}

B A R B A R A WA UCHOPE

$\mathrm{T}$

he transformation of a young dependent child to mature independent adult typically occurs from about age 13 to age 24 years, although there is much individual and cultural variation. During this period, the young person experiences change in almost all aspects of life. The physical body matures along with its reproductive capabilities. Cognitive, emotional, and psychosocial characteristics develop, particularly the capacity for judgment and self-regulation and strength and resilience. ${ }^{1}$ Along the way, individual growth interacts with society's expectations and opportunities for independence from the family, resulting in a wide range of behaviors that can affect the future of both the young person and the community.

This brief is an overview of some of the characteristics of New Hampshire's youth during this transitional period, including selected behaviors and outcomes of those behaviors that illustrate their vulnerability during this time. The truth inherent in the cliché that youth are our future makes it imperative that we have a clear picture of the upcoming younger generation, their problems, their needs, and their circumstances. With better information, we can help young people make successful transitions to mature and productive adulthood.

The purpose of the project is to highlight indicators of youth well-being, characteristics that raise awareness of the critical importance of the issues that may be of most concern for this age group in our state. This approach follows logically from the Kids Count work of the Annie E. Casey Foundation nationally and the Children's Alliance of New Hampshire locally, which funded this project. Kids Count monitors the well-being of children and young people using a set of carefully chosen representative indicators. This project uses that model but more narrowly focuses on a set of indicators that describe adolescents and young adults approximately age 13 to 24 years. ${ }^{2}$

The brief begins with the big picture of the demographics of this age group in the state and characteristics of their education, economic, and household circumstances. These are followed by a series of indicators describing some of the most commonly reported risky behaviors and outcomes of young people. These indicators were selected for several reasons: (1) they were known to be risk factors for the development of good physical and mental health, as well as relationships to others and society; (2) data were available for both the United States and New Hampshire, creating opportunities to compare our state to national averages; and (3) data were available over multiple years, allowing us to look at trends over time. The data are from federal and state agency sources and are the most recent available at the time of this publication (see the end of the brief for the sources of each indicator).

\section{Key Findings}

- Young people in New Hampshire's schools drop out less and complete high school and go on to college more than in the rest of the United States.

- Employment is higher and unemployment is lower among New Hampshire youth than elsewhere in the country.

- Poverty and obesity are lower in New Hampshire than nationally but are growing problems.

- Younger adolescents age 12 to 17 in New Hampshire use alcohol and marijuana at rates higher than the national averages but lower than the young adults.

New Hampshire young adults age 18 to 24 smoke tobacco, binge drink alcohol, and use marijuana and other illicit drugs at rates higher than national averages. 


\section{FIGURE 1.}

New Hampshire

YOUTH AGE 14

TO 24 IN EACH

COUNTY (2008)
PERCENT OF
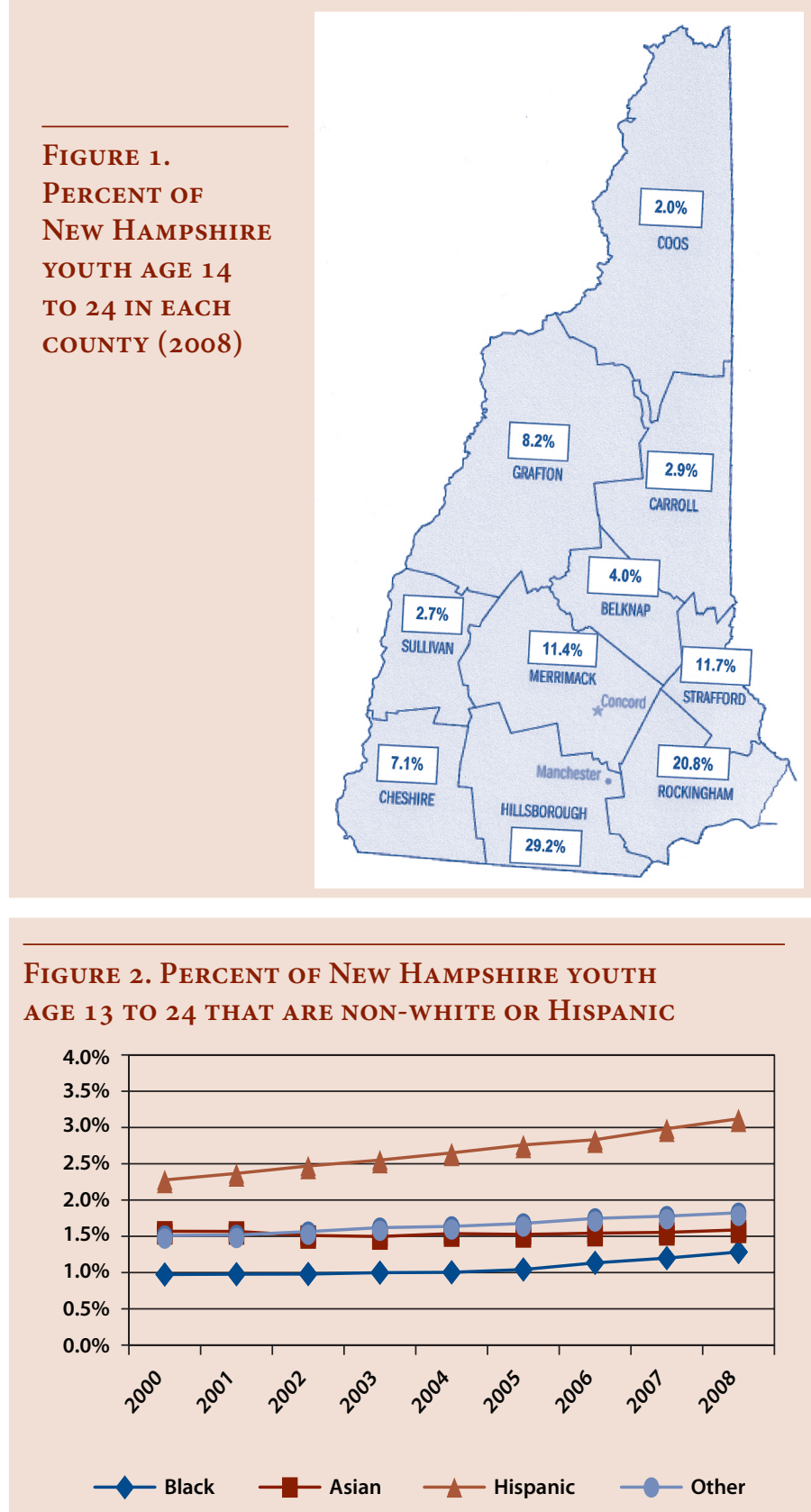

Figure 3. Percent of New Hampshire youth AGE 13 TO 17 OR 18 TO 21 WITH DISABILITIES

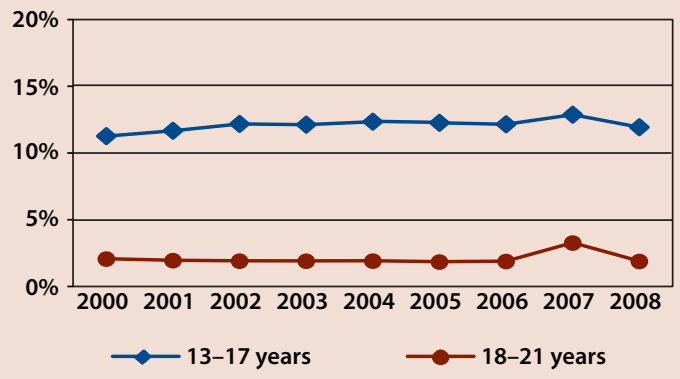

\section{New Hampshire's Youth Population}

Age

Young people age 13 to 24 years old are 8 percent of the total population of New Hampshire, a percentage that has not changed significantly in ten years. This percentage is less than half of that found in the United States overall (17 percent). In $2008,91,285$ (43 percent) of this age group were 13 to 17 years old; 119,114 (57 percent) were 18 to $24 .^{3}$

The numbers of young adults age 18 to 24 have steadily increased in the state and 13 to 17 year olds have declined slightly since 2005 . These changes reflect a period of high birth rates during the late 1980s, when the older group was born, and declining rates five years later. ${ }^{4}$

Like the rest of New Hampshire's population, more young people live in the southern counties than in the rest of the state (see Figure 1). In 2008, one-half of the youth population age 14 to 24 years lived in just two counties, Hillsborough and Rockingham. Coos County, the northernmost county in the state, had approximately 3,800 young residents; over 56,000 resided in Hillsborough County on the Massachusetts border.

Sex

For the last decade, males have slightly outnumbered females among New Hampshire youth age 13 to 24 years. In 2000, there were about 2 percent more males than females; the percentage difference doubled to about 4 percent in $2008 .^{5}$

\section{Race/Ethnicity}

New Hampshire youth are predominantly white, although the proportion has declined from 94 percent in 2000 to 92 percent in 2008. All non-white groups in the population have increased over the last decade, with Hispanic youth increasing the most (see Figure 2). From 2000 to 2008, the percentage of Hispanic youth in the state grew by 37 percent from 2.2 to 3.1 percent for a total population of almost 7,000 young Hispanics in 2008.

\section{Disabilities}

Young people with disabilities are a sizable group in New Hampshire, averaging about 15 percent of the youth population age 13 to 21. The percentage of New Hampshire's disabled youth population is similar to the percentage nationwide. About 7 percent of young people age 16 to 20 years in New Hampshire and in the United States have disabilities. ${ }^{6}$

Figure 3 shows the percentage of New Hampshire's population of younger and older youth with disabilities that are enrolled in public schools, a subset of all the disabled youth in the state. ${ }^{7}$ Although the population rose slightly in the early part of this decade, it has remained fairly stable for both groups in recent years. 


\section{Youth in Schools}

\section{Academics}

New Hampshire students are known for their academic achievement. In two of the standardized tests given to students nationally and in the state, New Hampshire students performed well above the national average. Since 2003, eighth graders in New Hampshire schools have averaged eight points higher on math and ten points higher on reading than the national average for the National Assessment of Education Programs (NAEP), commonly referred to as the Nation's Report Card. ${ }^{8}$

Historically, older students have also performed well on the Scholastic Achievement Test (SAT). Between 2000 and 2009, New Hampshire college-bound seniors scored consistently higher than the national average on both the reading and math tests (see Figure 4). As these scores have declined nationally over the last few years, average scores of New Hampshire seniors have risen, widening the gap between New Hampshire and the rest of the country on these tests.

\section{Graduation}

Most of New Hampshire's students graduate from high school at a rate consistently higher than the national average (see Figure 5). On average, 78 percent of high school freshmen graduate with a high school diploma, five percent more than the national average. Since 2000, the percentage of New Hampshire students graduating has been steadily increasing, while nationally, graduate rates have begun to decline. In 2008, 78 percent of New Hampshire freshmen graduated compared to 73 percent nationally.

Almost all students (99 percent) who complete high school in New Hampshire obtain a diploma. The other 1 percent complete it by successfully taking the General Educational Development (GED) test. ${ }^{9}$

\section{Dropouts}

Until recently, New Hampshire's annual dropout rate was almost as high as the national rate, but in the 2002-2003 school year, the rate began to fall compared to the rest of the country (see Figure 6). The cumulative dropout rate, which counts the number of students that dropout over the four-year period between freshman and senior year, has also declined in New Hampshire. Between the 2000-2001 and the 2008-2009 school years, the cumulative dropout rate declined by two-thirds ( 66 percent), from 19.7 to 6.7 , with almost one-quarter (24 percent) of that decline occurring during the last year. ${ }^{10}$
Figure 4. Average Scholastic Aptitude Test scores OF COLLEGE-BOUND SENIORS

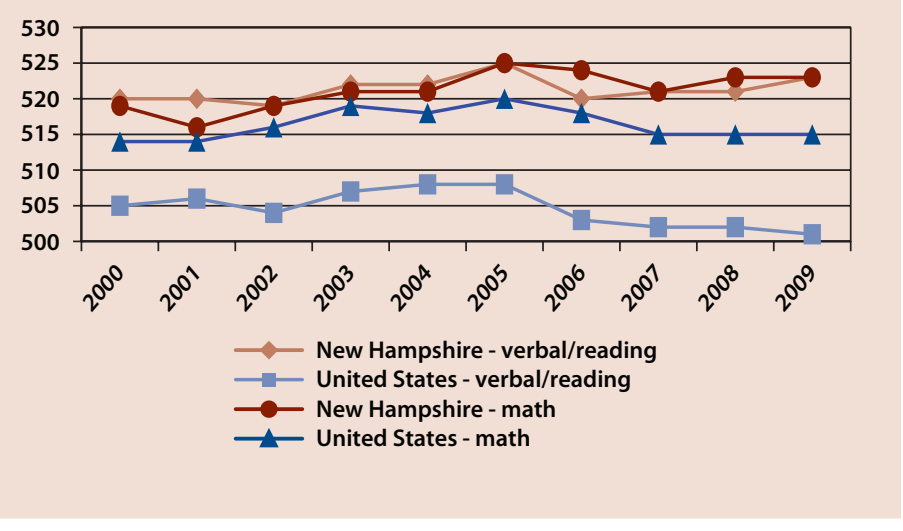

FIgURE 5. AVERAGE PERCENT OF HIGH SCHOOL FRESHMEN THAT GRADUATE WITH A HIGH SCHOOL DIPLOMA

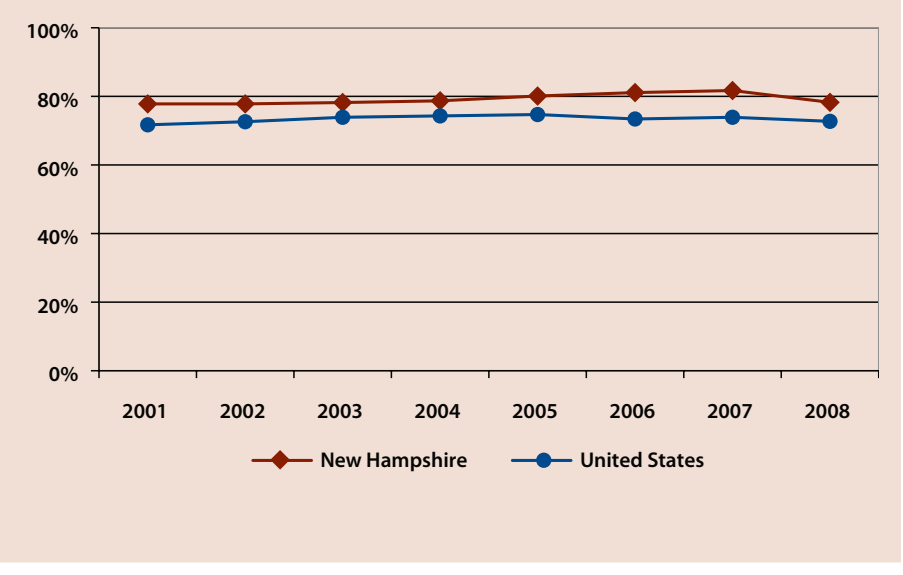

FIGURE 6. ANNUAL DROPOUT RATE IN PUBLIC SCHOOLS

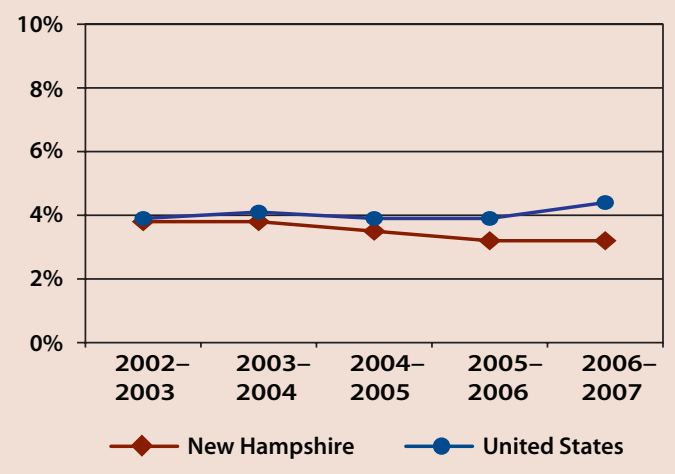




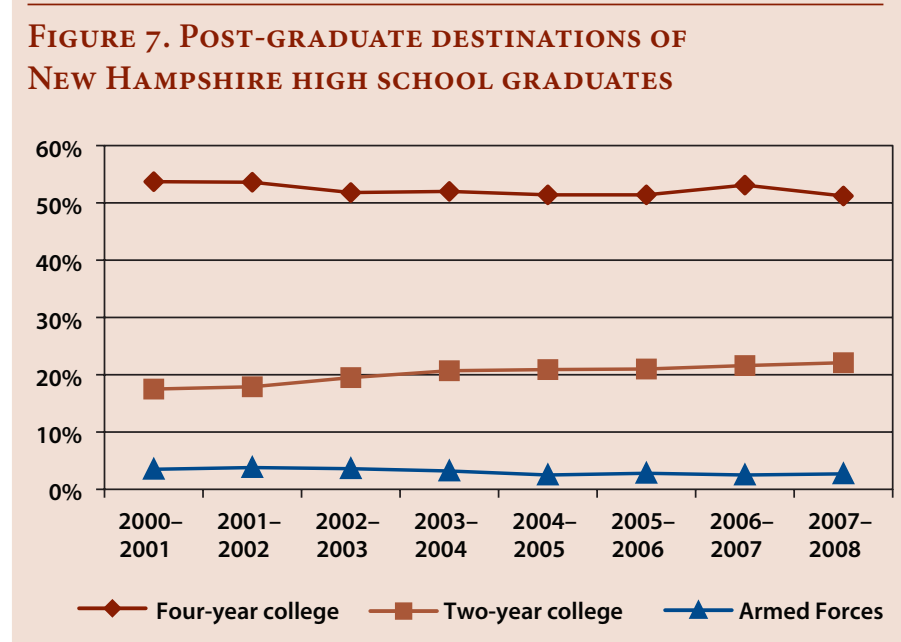

Figure 8. ESTIMATED PERCENTAge OF YOUTH AGE 16 TO 19 AND 20 TO 24 THAT ARE EMPLOYED

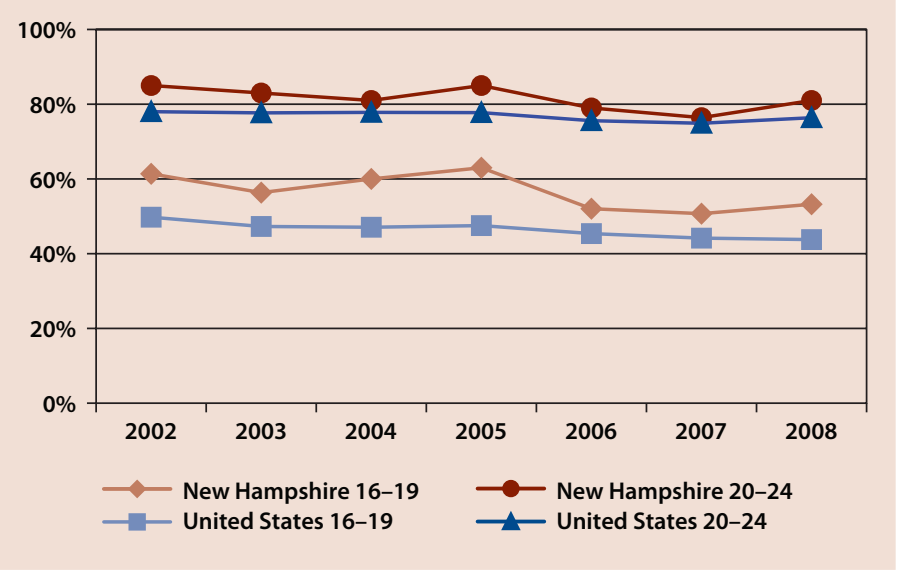

Figure 9. ESTIMATED PERCENTAGE OF YOUTH AGE 16 TO 19 AND 20 TO 24 THAT ARE UNEMPLOYED

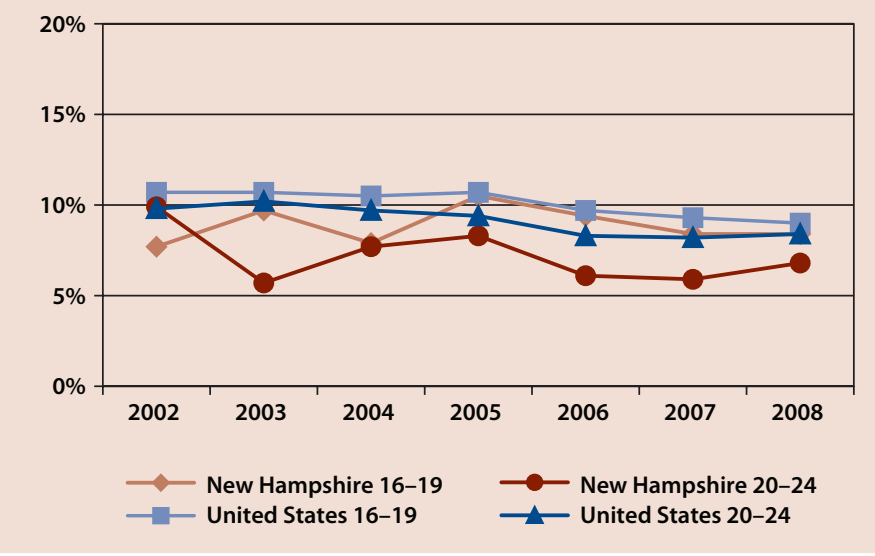

\section{Suspensions}

One of the factors known to put students at risk of dropping out is repeated suspensions. In 2006, a U.S. Department of Education survey found that, on average, New Hampshire suspends high school students at a rate about 1 percent lower than the national rate. ${ }^{11}$ However, a recent report analyzing data collected by the New Hampshire Department of Education from every school in the state found that for 2007-2008, the out-of-school suspension rate of 8.3 percent was higher than the rate of 6.9 percent found in a 2006 national survey. ${ }^{12}$ Over one-half (57 percent) of those suspensions involved high school students, and 21 percent involved middle or junior high school students. ${ }^{13}$

\section{Beyond High School}

\section{College and the Military}

According to a survey conducted by the New Hampshire Department of Education during the summer after high school graduation, the majority of New Hampshire youth go on to college (see Figure 7). Over 50 percent go to a four-year college and about 20 percent more enroll in a two-year college. Since 2000, the percentage of students enrolled in two-year colleges has increased, while the percentage attending fouryear colleges has declined slightly.

About 3 percent of students enter the armed forces, a number that has declined about 1 percent since 2000 .

\section{Employment}

Whether or not young people are attending school, most of them are employed at least part-time or part of the year. More New Hampshire youth are employed in the state than their peers in the rest of the country (see Figure 8 ). The trend for youth employment throughout most of the last decade has been downward, particularly for adolescent workers.

\section{Unemployment}

Estimates show slightly increased unemployment rates among adolescents but slightly decreased unemployment rates among young adults over the last seven years (see Figure 9).

Although unemployment is always a concern for any working age group, when young people find themselves unemployed, they often choose to finish high school or attend college if they cannot find work. Of particular concern are youth who neither work nor attend school, often referred to as "idle youth." Five percent of New Hampshire adolescents age 13 to 17 are not working or in school compared to the national average of 9 percent. The rate for idle young adults age 18 to 24 in New Hampshire is 9 percent compared to 15 percent nationwide. 


\section{Youth in Poverty}

\section{Adolescents}

The current recession and its impact on income and housing is a major concern not only for adolescent children in families but also for adolescents and young adults struggling to live on their own and particularly for young people who have children. It is still too early for much data describing these changing circumstances to be available; however, the data we do have shows the beginning of trends reflecting the economic recession.

Federal child nutrition and supplemental food programs, including the National School Lunch and Breakfast programs and the Supplemental Nutrition Assistance Program (SNAP) give families increased access to nutritious food and meals. Eligibility for these programs is often used as a measure of the poverty of families.

The percentage of students participating in the National School Lunch and Breakfast programs has increased among New Hampshire high school students since 2004 (see Figure 10), indicating growing poverty among New Hampshire families. Between the 2004-2005 and the 2009-2010 school years, the percentage of high school students eligible for a free and reduced lunch increased by 55 percent to one-fifth or 12,604 New Hampshire high school students.

Recent data suggests that rates for participation in SNAP among 12 to 17 year olds are increasing, although they remain below the national rate. Nationally, the percent of youth ages 12 to 17 participating in the SNAP program was 13 percent in 2008. ${ }^{14}$ Among New Hampshire adolescents in this same age range, participation in SNAP increased from 8.5 percent in April 2009 to 9.2 percent in February 2010. ${ }^{15}$

\section{Young Adults}

Among older youth age 18 to 24, we have less current data, and there is less evidence that poverty is as serious a problem as it is among the younger adolescents. Compared to the rest of the country, fewer young adults in New Hampshire are living in poverty (see Figure 11). On average, an estimated 15 percent of New Hampshire young adults age 18 to 24 live in poverty, with a slight trend upward over most of the past decade.

New Hampshire is one of the five states with the highest median incomes in the country. ${ }^{16}$ It is also in the top ten of states with the highest cost of living. ${ }^{17}$ Any young person trying to make a living and get by, particularly during the current recession, faces a challenging economic environment. A key indicator of this challenge is the amount of income it takes a young adult to live independently. Since 2002, a growing percentage of young people age 15 to 24 are spending more than one-quarter of their income on rent, surpassing the national average in 2008 (see Figure 12).

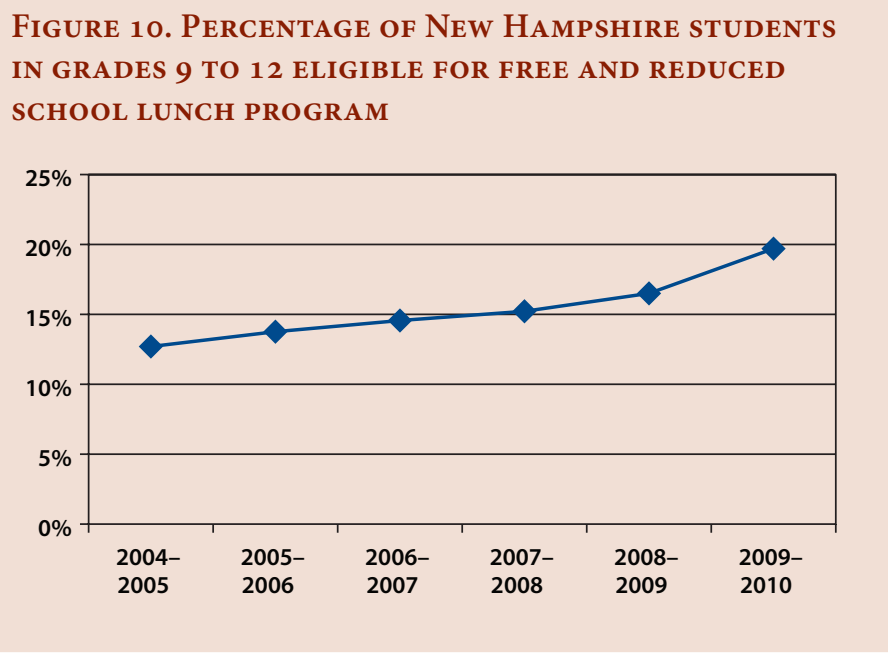

Figure 11. ESTIMATED PERCENTAGE OF YOUTH AGE 18 TO 24 LIVING IN POVERTY

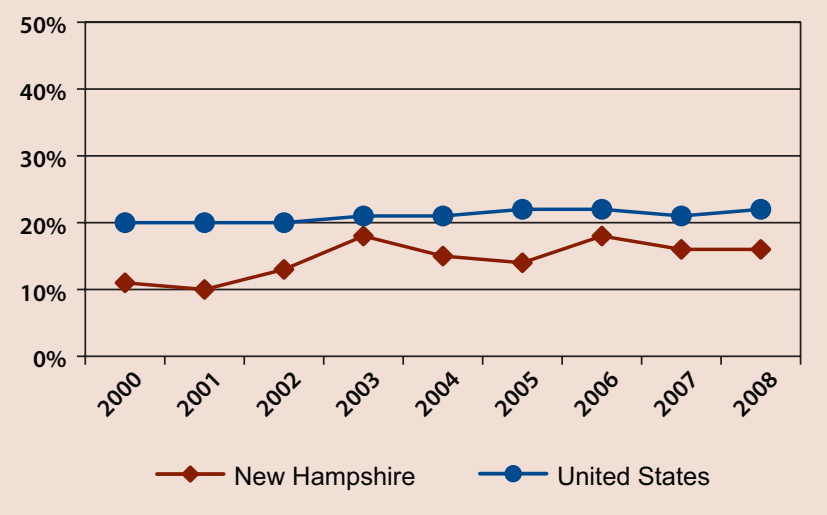

Figure 12. Percent of young PeOPle Age 15 to 24 SPENDING MORE THAN 25 PERCENT OF INCOME ON RENT

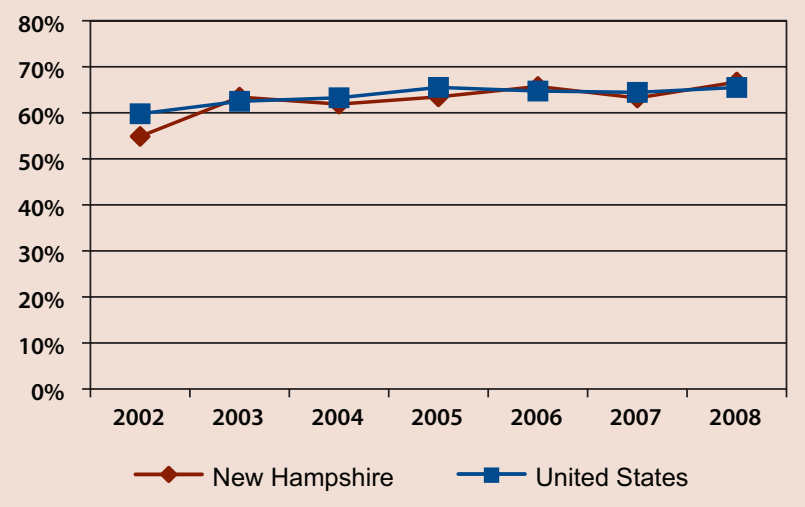




\section{Figure 13. Percentage of youth Age 15 TO 19 WHO LIVE IN SINGLE-PARENT HOUSEHOLDS}

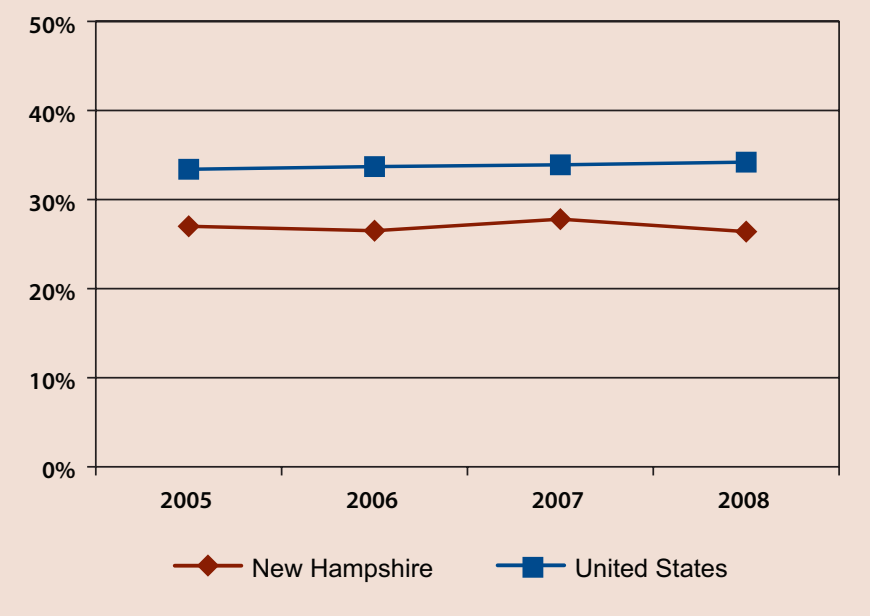

Figure 14. NUMBER OF HOMELESS STUDENTS IN GRADES 9 TO 12 attending New Hampshire PUblic SCHOOLS

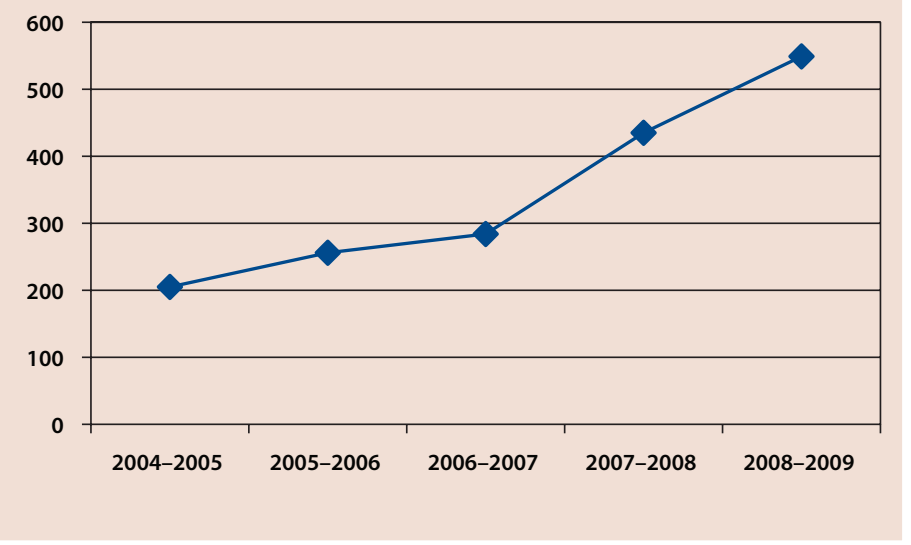

FIgURE 15. LIVE BIRTHS TO YOUNG WOMEN AGE 15 TO 19 AND 20 TO 24

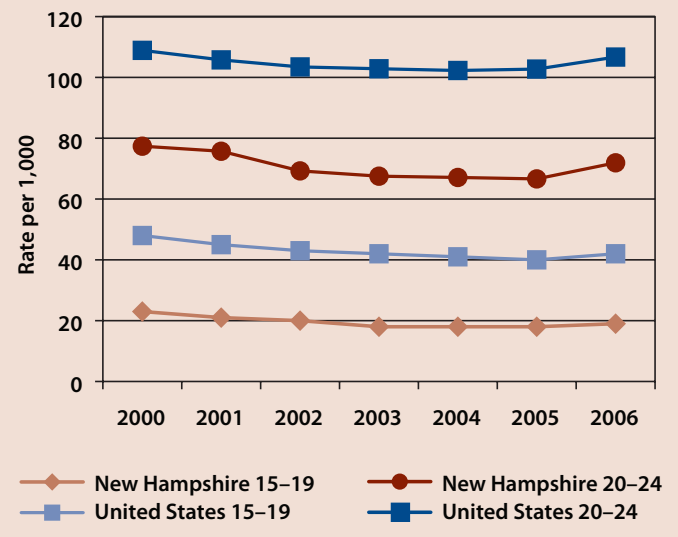

\section{Living Arrangements}

\section{Household}

The high cost of living in New Hampshire probably contributes to many New Hampshire youth residing with parents or relatives. In 2008, the majority (70 percent) of New Hampshire youth age 15 to 19 lived with married parents, which was more than the national average ( 62 percent). More than one-quarter (26 percent) lived in single-parent households (see Figure 13). A small percentage (2 percent) of 12 to 17 year olds live with caregiver grandparents, one-half the national rate of 4 percent. ${ }^{18}$

\section{Homelessness}

Some adolescents in New Hampshire are living in unstable housing situations. These are the homeless youth who live on their own or with relatives or friends, sleeping on the street, on a couch, at a shelter, or in temporary housing. Since the 2004-2005 school year, the number of homeless high school students in New Hampshire has increased 167 percent (see Figure 14).

Many of these homeless young people are difficult to identify as homeless because they stay with friends, moving from place to place, and often do not reach out for help. This is particularly true for the older youth, young adults who aged out of state-run care or confinement when they turned 18 , and other young people who are on their own but having difficulty finding or holding jobs and housing. Between the population of adolescents under 18 and the young adult homeless, the number of homeless youth in New Hampshire is estimated at over 1,000 young people each year. ${ }^{19}$

\section{Marriage and Divorce}

In New Hampshire, the age of consent for marriage is 18 . With a parent or guardian petition to the court, girls can marry at 13 and boys at $14 .{ }^{20}$ The number of girls who marry at a young age annually, however, is small and has been declining since 2002. On average, about 1,000 girls between age 15 and 24 in New Hampshire marry in any given year. ${ }^{21}$ Most of the marriages occur at the upper end of the age range (early twenties), which probably explains the low number of divorces for this age group: one out of ten, a number that has been consistent over the decade. ${ }^{22}$

\section{Births}

Since 2000, birth rates for young women in the state and the country, married and unmarried, have declined. This trend appeared to end in 2006 and 2007, with a slight increase. ${ }^{23}$ The average rate for New Hampshire women age 15 to 19 is less than half the rate of women nationally; for older women, it is two-thirds the national rate (see Figure 15). 


\section{Behaviors and Outcomes}

In this section, we present a set of indicators for some of the most commonly reported risky behaviors practiced by young people and their outcomes. The relationships between these behaviors are complicated: some consequences are behaviors themselves, and often multiple behaviors are involved. Many are known to be a result or cause of longer-term problems that young people experience on their own, as part of families or groups of friends.

\section{Sexuality}

Learning about their own sexuality and managing sexual relations with others is a process that dominates the personal lives of many, if not most, adolescents and young adults. In New Hampshire, a smaller percentage of adolescents have been sexually active than among teens nationally, although this may be changing (see Figure 16). Between 2003 and 2009, the percentage of New Hampshire high school students who were sexually active increased by 5 percent.

At the same time that sexual activity is increasing among high school students, the prevalence of chlamydia, a sexually transmitted disease that can have long-term effects on reproductive health, is also rising gradually among this age group, although it remains lower than in the rest of the country (see Figure 17). Rates of gonorrhea among young people in New Hampshire have been declining since 2005. In 2008, the rate for those 20 to 24 years old was 34 cases per 100,000 and 15 cases among 13 to 19 year olds. ${ }^{24}$

Human Immunodeficiency Virus (HIV) currently occurs at less than 1 case per 100,000 among adolescents age 13 to 19 in New Hampshire. Among 20 to 24 year olds, the $\mathrm{HIV}$ rate has declined over the last three years to 2 cases per 100,000 in $2008 .^{25}$

\section{Diet}

The epidemic of childhood obesity that has emerged over the last decade is a major health problem with far-reaching consequences for the long-term health of young people. Among New Hampshire high school students, the problem of obesity is growing (see Figure 18). In 2009, 12 percent of high school students surveyed in the state reported body mass index numbers that indicated obesity, up from 10 percent six years earlier.

The flip side of the behaviors that cause obesity and overweight in youth is the problem of eating disorders, behaviors associated with trying to stay thin. Although the data are incomplete, they suggest that a smaller percentage of New Hampshire adolescents report binge-purge behaviors to control weight than adolescents nationally. ${ }^{26}$

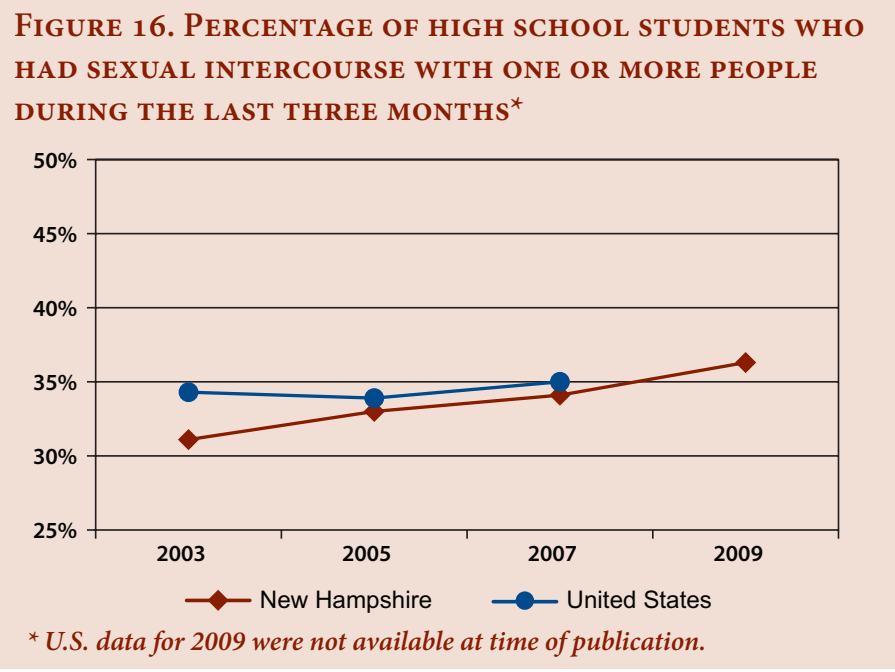

Figure 17. NUMBER OF CASES OF CHLAMYDIA AMONG YOUNG PEOPLE BY AGE GROUP

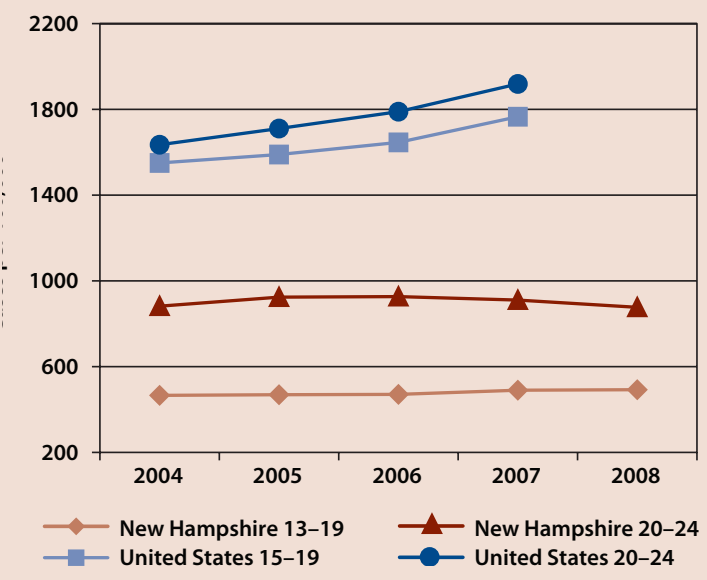

Note: Data were not available for identical age ranges for New Hampshire and U.S. adolescent rates. Because of the small number of cases for 13 and 14 year olds, including them in the New Hampshire rate did not affect the rate for that age range.

Figure 18. Percentage of high SChool students WHO WERE OBESE (AT OR ABOVE 95 TH PERCENTILE FOR BODY MASS INDEX)*

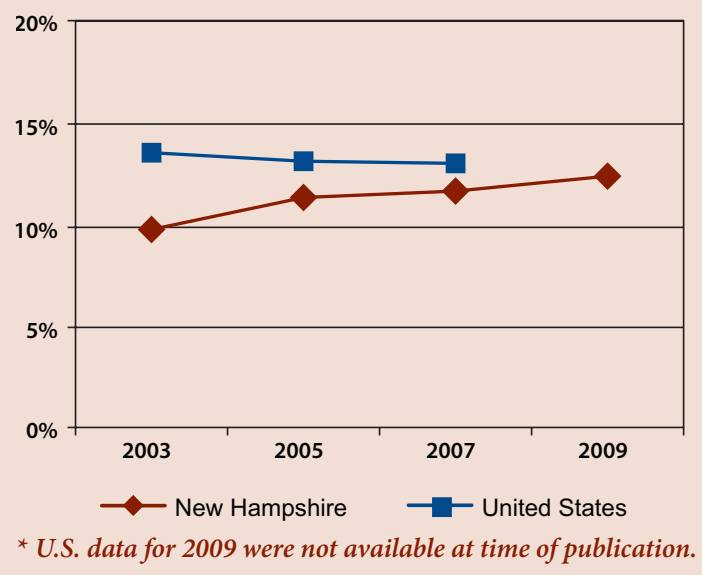




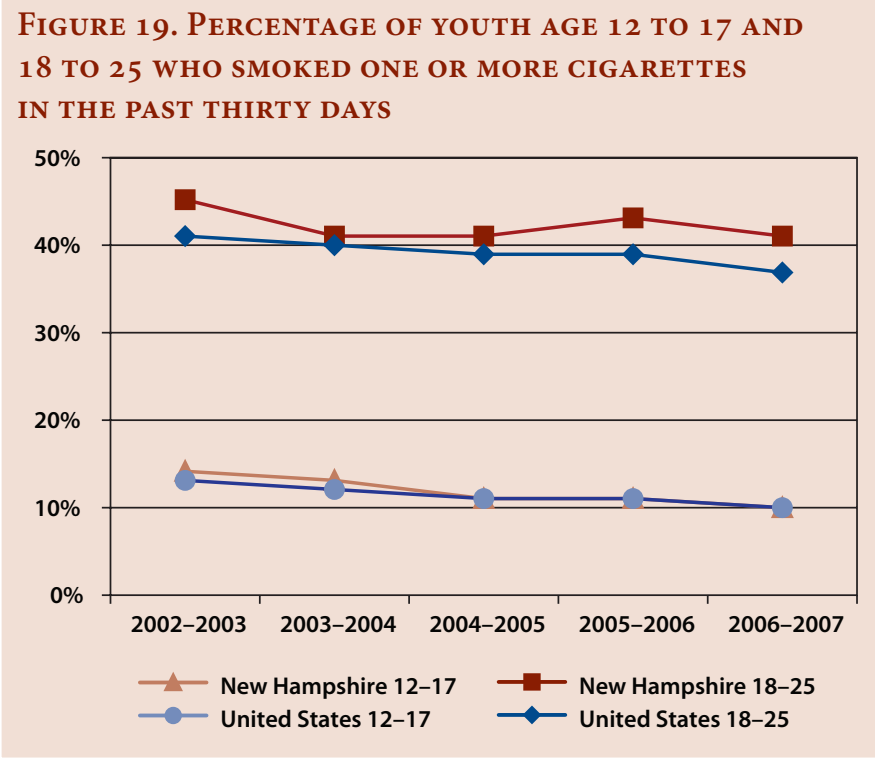

Figure 20. Percentage of high SCHOOL STUdents WHO WATCHED VIDEO OR WHO PLAYED COMPUTER GAMES OR USED A COMPUTER FOR SOMETHING THAT IS NOT SCHOOL WORK THREE OR MORE HOURS PER DAY ${ }^{*}$

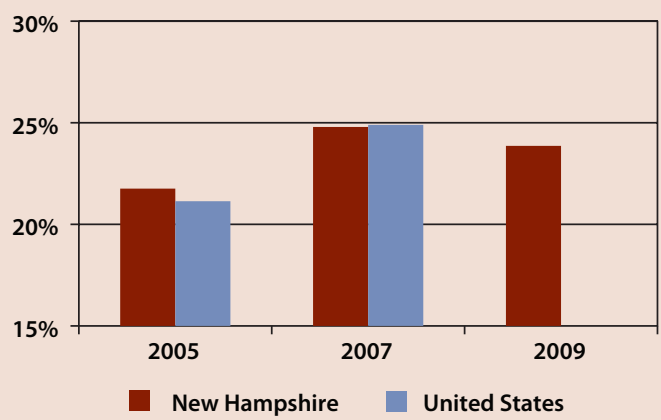

* U.S. data for 2009 were not available at time of publication.

Figure 21. Percent of total traffic fatalities of YOUNG PEOPLE AGE 16 TO 20 AND 21 TO 24 INVOLVING DRIVERS AGE 24 YEARS OR YOUNGER

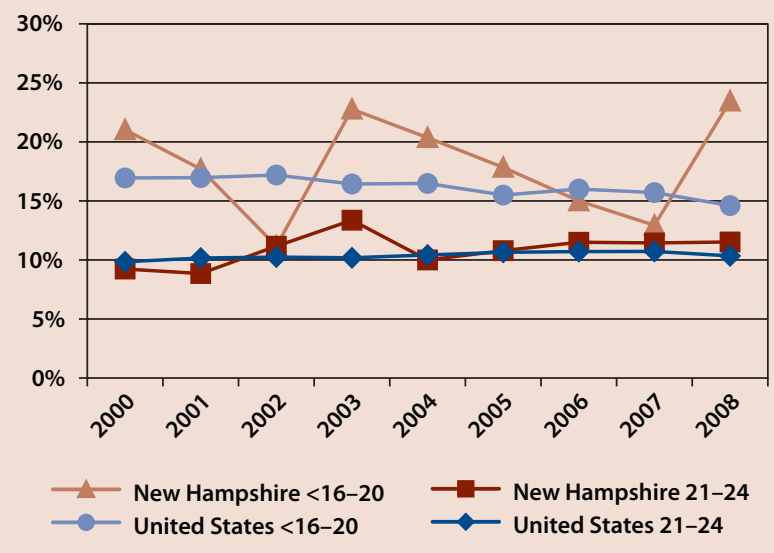

\section{Smoking}

The health effects of smoking cigarettes and using tobacco products are not usually seen until long after youth become adults. As a social problem, smoking cigarettes is declining nationally (see Figure 19). Although New Hampshire's rates for young teens that smoke have dropped below the national rates in the last few years, the young adult rates remain higher than the average in the rest of the country. Over 40 percent of 18 to 25 year olds reported smoking a cigarette at least once in the previous month.

\section{Video Exposure}

Many of today's youth spend free time playing video games, messaging social networking sites, listening to music, watching television, talking on cell phones, or often doing several of these activities simultaneously. Some studies suggest that the long hours being physically inactive while mentally multitasking in front of a video screen has negative effects on young people. Among the problems uncovered in this early research are video addiction, ${ }^{27}$ reduced ability to focus attention for long periods of time, ${ }^{28}$ and depression. ${ }^{29}$

Although there are no data yet on these outcomes, there is enough concern that the Centers for Disease Control and Prevention is beginning to collect data on the behaviors. Early findings show that New Hampshire youth are not much different from their peers in the rest of the country. In 2007, about 24 percent of high school students in New Hampshire spent three or more hours watching videos or using computers for leisure, slightly less than the percentage nationally (see Figure 20).

However, New Hampshire students watch less television than other high school students in the country. One-quarter (25 percent) of New Hampshire high school students watch three or more hours of television per day compared to 37 percent of other U.S. students. ${ }^{30}$

\section{Traffic Accidents}

Most young people in New Hampshire obtain a driver's license at age 16 , usually after learning how to drive with a learner's permit at age 15 . Inexperience combined with a stilldeveloping capacity to make good decisions make youth vulnerable to automobile and motorcycle accidents and injuries.

The actual numbers of accidents that occur in New Hampshire are low compared to most places in the country. Consequently, an increase or decrease of a small number of accidents from one year to the next due to road conditions, for example, can have an impact on trends over time. Figure 21 illustrates this problem. Nonetheless, traffic fatalities of young people in New Hampshire have been higher than the national average among adolescents and young adults for six out of the last nine years. Out of all the traffic accidents in New Hampshire between 2000 and 2008 involving young drivers, 18 percent caused fatalities among 16 to 20 year olds. 


\section{Alcohol}

One of the factors in the traffic accidents described above is the problem of drinking and driving. Young people in New Hampshire report less of this behavior than in the rest of the country. In the Youth Risk Behavior Survey of New Hampshire high school students from 2003 to 2009, about 24 percent on average reported that they rode one or more times during the past thirty days in a vehicle driven by someone who had been drinking alcohol. The average for the country is 29 percent. ${ }^{31}$

Binge drinking has emerged as a particularly serious problem among young people. Parties with drinking games that promote binge drinking are popular at colleges and universities. Among New Hampshire youth, this culture appears to have taken hold. Data from the National Survey on Drug Use and Health shows that rates of binge drinking are higher in New Hampshire than the national rates for both adolescents and young adults. While the rate for young adults in the United States remains level, the percentage of binge drinking young adults in New Hampshire rose between 2004-2005 and 2006-2007. Binge drinking among younger teens declined slightly between 2003-2004 and 2006-2007 (see Figure 22).

\section{Marijuana and Other Illegal Drugs}

New Hampshire young people, both adolescents and young adults, smoke marijuana at rates higher than the rest of the country (see Figure 23). For most of the last five years, the percent of youth age 12 to 17 smoking marijuana has been declining, but the last survey showed an increase. Young adults in New Hampshire that smoke marijuana do so at rates averaging 50 percent higher than the national rates.

In addition to marijuana, which is the most popular illegal drug in New Hampshire, cocaine, crack cocaine, heroin, and methamphetamines are easily obtained by young people, in part because of proximity to the major drug trafficking centers of Lowell and Lawrence, Massachusetts. ${ }^{32}$ For four of the last five years, illegal drug use among young adults in New Hampshire has been higher than the national rates (see Figure 24).
Figure 22. YOUTH AgE 12 TO 17 AND 18 TO 24 WHO DRANK FIVE OR MORE DRINKS IN A ROW SOMETIME IN THE LAST THIRTY DAYS

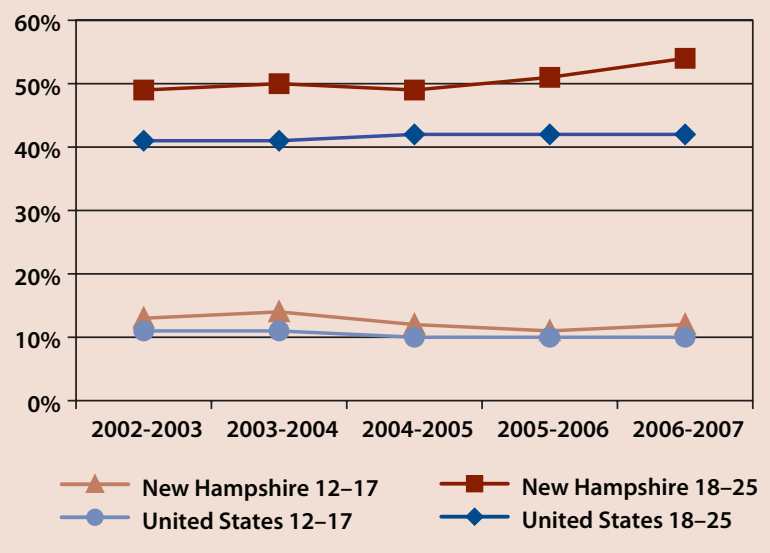

FIGURE 23. YOUTH AGE 12 TO 17 AND 18 TO 24 WHO SMOKED MARIJUANA SOMETIME DURING THE LAST THIRTY DAYS

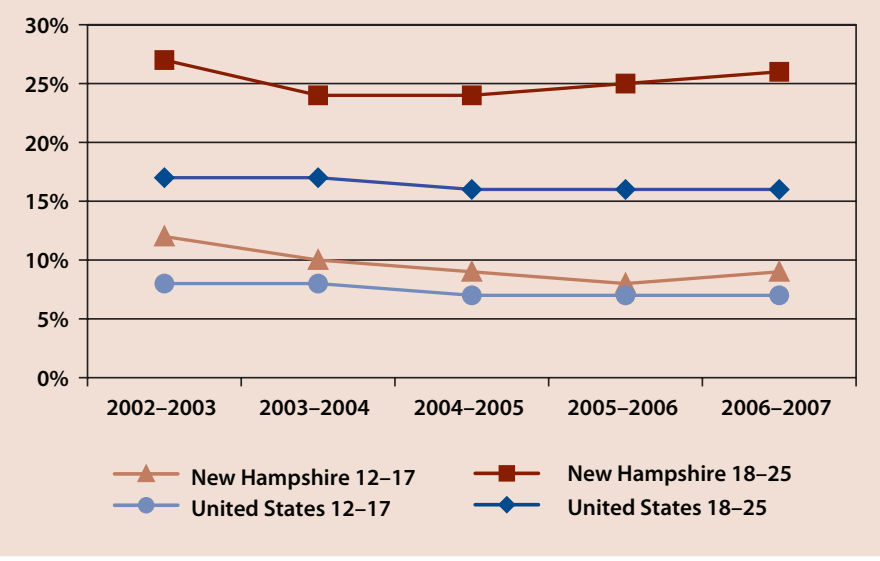

Figure 24. YOUTH AGE 12 TO 17 AND 18 TO 24 WHO USED OTHER ILLICIT DRUGS SOMETIME IN THE LAST THIRTY DAYS

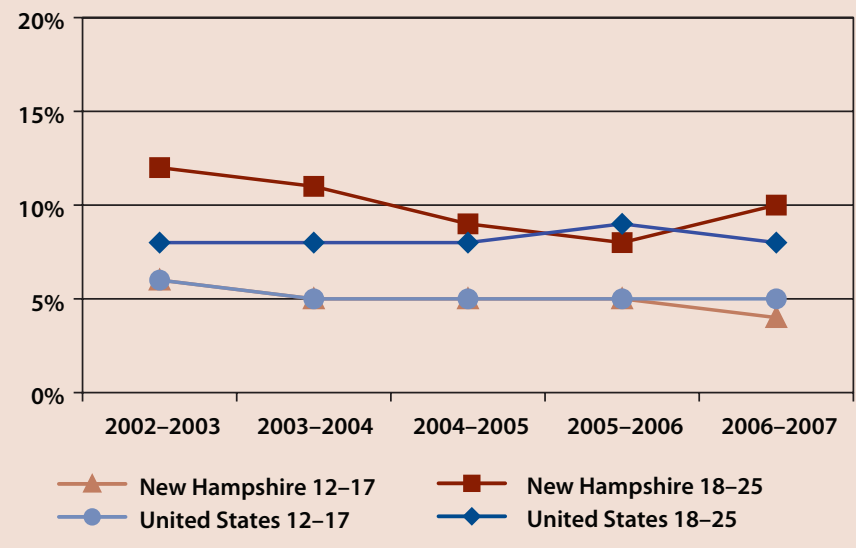




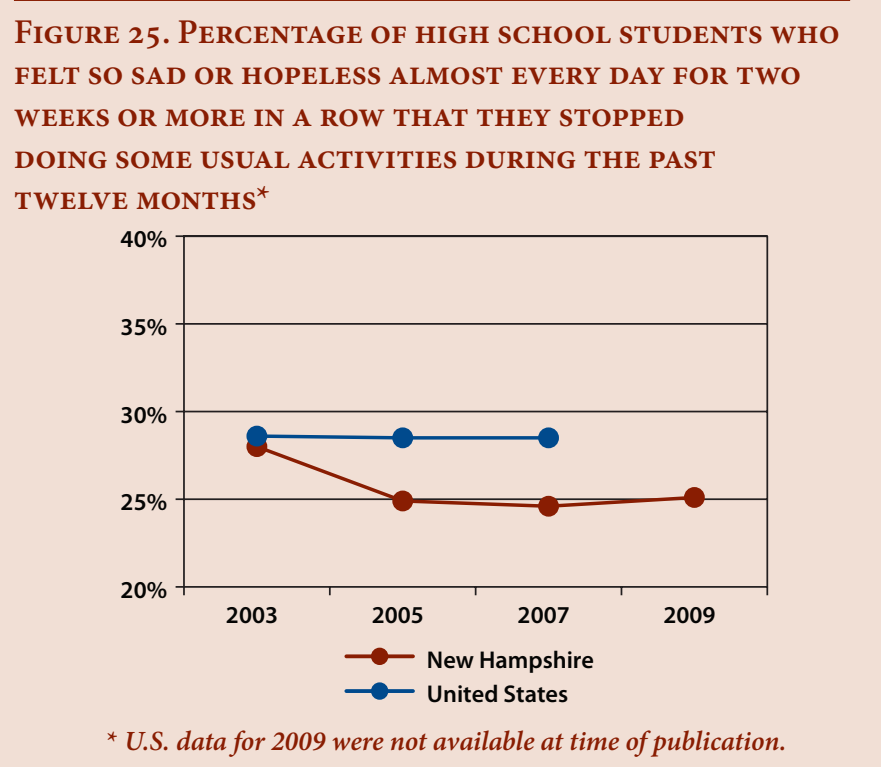

FIGURE 26. RATE OF SUICIDE DEATHS OF YOUNG PEOPLE AGE 15 TO 19 AND 20 TO 24 YEARS

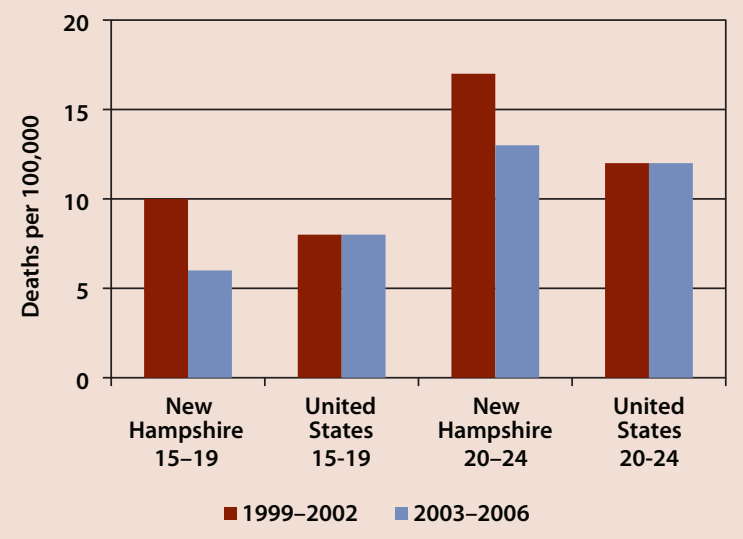

Figure 27. PERCENT OF HIGH SCHOOL STUDENTS WHO REPORTED BEING THREATENED OR INJURED BY A WEAPON ON SCHOOL PROPERTY DURING THE PAST TWELVE MONTHS

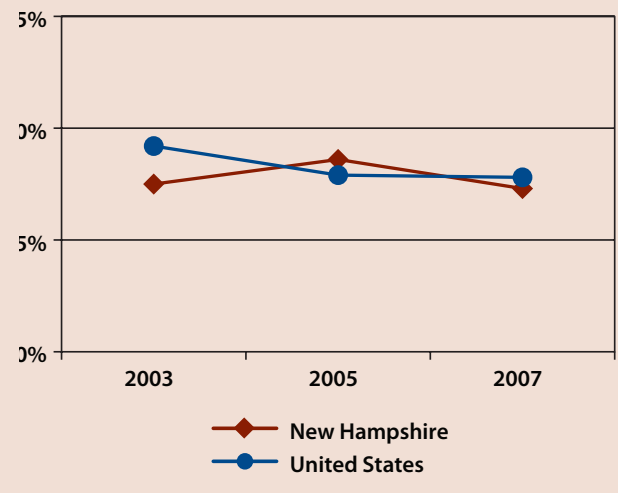

\section{Depression}

Because of the moodiness and changeability so characteristic of adolescents and young adults, mental illness often goes undiagnosed and untreated until they are older. However, it is of special concern for this age group because some of the most serious mental illnesses, particularly depression and schizophrenia, often emerge in the late teens or early twenties. Even temporary feelings of depression as a result of a failed relationships or poor test results can sometimes derail young people. The percentage of New Hampshire high school students reporting evidence of depression has averaged about 26 percent over the last six years, lower than the national rate of 29 percent (see Figure 25).

\section{Suicide}

Suicide can be one outcome of depression and other mental illness. Among young people, particularly adolescents, suicide is rare. For a small state like New Hampshire, this means that annual data must be combined over several years to produce enough cases for a rate. In New Hampshire, although the numbers are small, the rate of suicide among young adults has been higher than the national rate for ten years, although it declined during the second half of the decade (see Figure 26).

\section{Youth Violence}

Young people can be victims of violence from others, aggressors themselves, or both. Bullying often starts well before adolescence. By the time a child reaches his teens, patterns of victimization and aggression can be well established within groups of youth in and out of school. We do not have an indicator for bullying except for the experience of being threatened or injured at school, which may or may not be bullying. Between 2003 and 2007, about 8 percent of high school students in New Hampshire reported that they experienced threats or injuries from weapons at school, a rate similar to the national rate (see Figure 27). 
Dating violence is often the precursor to long-term domestic violence and abuse. The violence is often verbal and emotional, as well as physical, such as date rape and other sexual assault. Dating violence among New Hampshire high school students is lower than the national rate, but both rates appear to be increasing (see Figure 28).

Young people who get into fights risk serious injury, especially if a knife or other weapon is involved. Fights at school can also lead to suspensions and other harsh consequences. Nationally, over one-third of high school students report fighting sometime over the past year, but fewer than 30 percent of New Hampshire students report fighting (see Figure 29). In 2007, 18 percent of New Hampshire high school students surveyed reported carrying a weapon at least one day during the previous month, up from 15 percent four years earlier. ${ }^{33}$

\section{Crime and Delinquency}

Compared to many states in the country, New Hampshire's delinquency problem is small. Juveniles are apprehended primarily for drug and property crime offenses. Arrests for drug offenses have declined in New Hampshire and are similar to the national rate (see Figure 30 ). The rate of property crime arrests in New Hampshire is less than two-thirds the arrest rate in the rest of the country.

Nonetheless, a large number of adolescents are arrested every year in New Hampshire. Six percent $(8,797)$ of the juvenile population of New Hampshire age 10 to 17 were arrested in 2006. Of those, about 2,000 were declared delinquent by a court. ${ }^{34}$

In New Hampshire, juveniles under the age of 17 may be detained while waiting for the court to hear their cases or for placement into alternative community-based programs. Juveniles may be detained at a youth detention center or may be held in county jails, depending on the offense. Those who are found guilty of criminal offenses are committed to the Sununu Youth Services Center, a residential facility that provides academic, residential life, and behavioral remediation programs.
Figure 28. PERCENT OF HIGH SCHOOL STUDENTS WHO WERE HIT, SLAPPED, OR PHYSICALLY HURT ON PURPOSE BY A BOYFRIEND OR GIRLFRIEND DURING THE PAST TWELVE MONTHS ${ }^{*}$

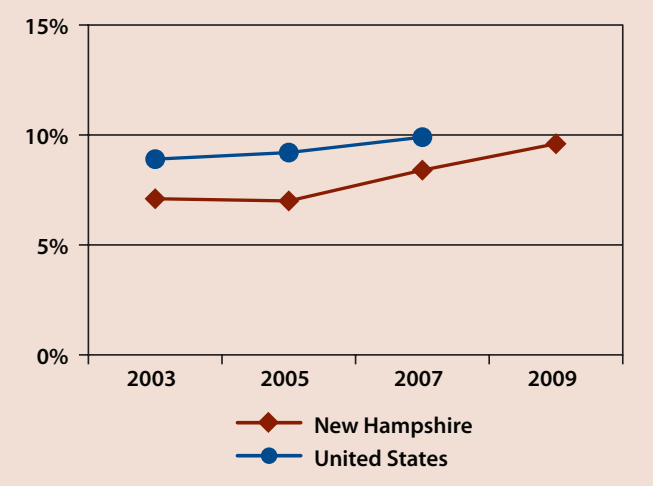

* U.S. data for 2009 were not available at time of publication.

Figure 29. PERCENT OF High SCHOOL STUdENTS WhO REPORTED HAVING BEEN IN A PHYSICAL FIGHT DURING THE PAST TWELVE MONTHS ${ }^{*}$

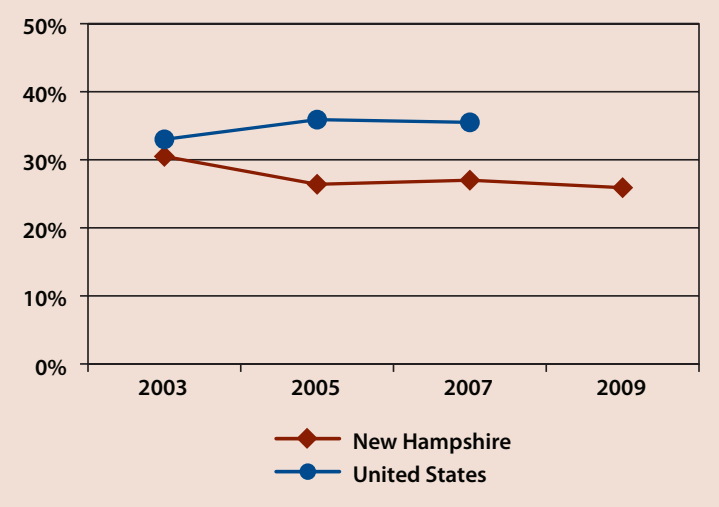

* U.S. data for 2009 were not available at time of publication.

Figure 30. JUVENILE (AGE 10 TO 17) ARREST RATE FOR DRUG ABUSE AND PROPERTY CRIME OFFENSES

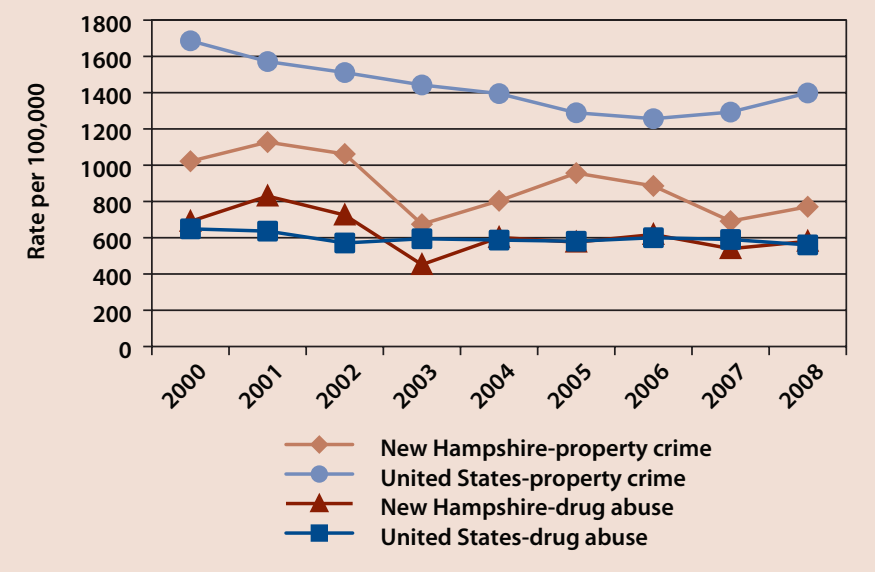


FigURE 31. RATE OF JUVENILES (AGE 10 TO 17) HELD IN CUSTODY IN YOUTH RESIDENTIAL PLACEMENT FACILITIES

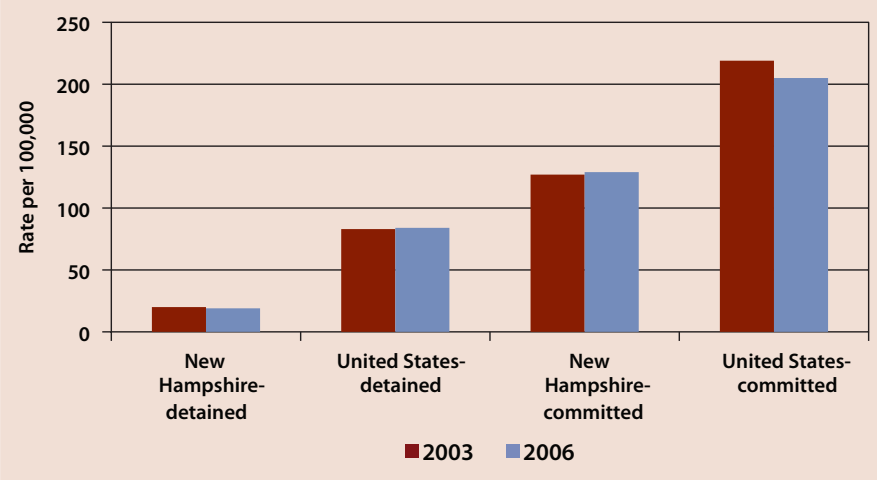

FIgURE 32. YOUNG ADULT INMATES AGE 17 TO 21 AND 22 TO 25 IN NEW HAMPSHIRE STATE ADULT CORRECTIONAL FACILITIES

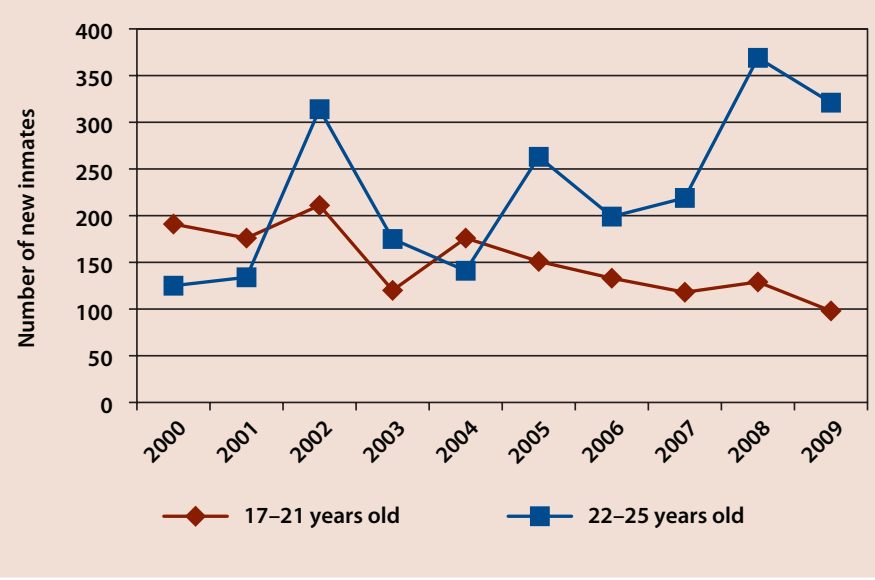

Rates of detention and commitment are lower in New Hampshire than in the United States overall and did not change significantly between 2003 and 2006 (see Figure 31). In 2007, 260 juveniles were held at a youth detention center; 189 delinquents were confined at the Sununu Youth Services Center.

Young adult offenders, 17 years and older, serve their sentences in one of the state or county adult residential facilities. In 2009, young adults made up 15 percent of the population of state correctional facilities, with about four times as many in the 22 to 25 age group as in the 17 to 21 age group. While the number of young offenders in state facilities is declining, the trend for older offenders has seen an increase (see Figure 32). 


\section{Summary and Conclusions}

Young people in New Hampshire outperform their peers in the rest of the country on many indicators of well-being. They excel in academics and complete high school at higher rates, while dropping out less than students in the rest of the nation. Over 70 percent go on to college and most are employed, with fewer living in poverty than elsewhere in the United States. They are less likely to live with single parents or become parents themselves at a young age. New Hampshire youth are less sexually active for their age and contract sexually transmitted diseases at lower rates than youth in other states. Also, fewer young people in New Hampshire report obesity or depression, threats or injuries at school, and dating violence or physical fighting. Arrest rates for drug and property crimes are lower for New Hampshire youth. All these positive signs keep adolescents and young adults from stalling or falling behind in their transition from youth to full adulthood and participation in society.

There are, however, areas in which New Hampshire's young people, particularly the young adult population, lead their peers in risky behaviors. Young adults in New Hampshire smoke tobacco, binge drink, and use marijuana and other illicit drugs at rates higher than in the rest of the country. Although the numbers are small, their suicide rate is also higher than the national average. For most of the last decade, New Hampshire's adolescents age 16 to 20 have had high rates of fatal traffic accidents. Young adolescents also drink alcohol and use marijuana at rates that are higher than the national average but not as high as New Hampshire's young adults, and it appears that the trend for binge drinking is declining slightly in this group. The abuse of tobacco, alcohol, and drugs has documented negative effects on mental and physical health. There is increased risk of young people experiencing declines in school and job performance, as well as the deterioration of relationships with family, friends, and community.

Among these indicators is also evidence of growing economic instability among New Hampshire's youth. The percent of students eligible for the federal school meals programs, a measure of poverty, has steadily increased over the last five years. Larger percentages of young people spend more than a quarter of their income on rent, and the numbers of homeless high school students are going up. Also, the count of young adults age 22 to 25 imprisoned in New Hampshire has increased throughout most of the decade. And obesity is rising among New Hampshire's high school students, as is dating violence.
These challenges to the economic, social, and psychological well-being of young people come at a stage in their lives when they are least able to manage them. The areas of their brains and the regulatory systems that govern emotions and behavior are among the last to attain full maturation, often developing as late as the mid-twenties. Consequently many young people lack the capacity and skills to appropriately inhibit or modify behaviors that would help them avoid negative future consequences. As evidence of the vulnerability of young adults, research has found an overall increase in illness and death of between 200 and 300 percent during middle childhood, late adolescence, and early adulthood. ${ }^{35}$ Yet governmental policies state that at age 18 children become legal adults. For children in foster care or juvenile detention, releasing them from state oversight back into the community leaves them with few, if any, supports at a time when they are immature and unprepared for many adult responsibilities.

The indicators we have reviewed for this brief suggests that the problems that arise for New Hampshire's young people are concentrated in one area: involvement with substance use and abuse. Alcohol and drug use are at the center of a constellation of other problems from traffic accidents to mental illness and suicide and from the inability to stay in school and hold a job to delinquency and crime.

New Hampshire is a small, well educated, and largely wealthy state. ${ }^{36}$ We have the social and human capital and financial ability to help young people successfully navigate their transition from youth to adulthood without getting involved in substance use and abuse. We hope that with this brief, more attention will be focused on this critical period in the life of our youth and the resources needed to address its challenges. In a state where a first-class way of life is assumed and valued, it is essential to provide the supports young people age 13 to 24 need to become productive members of the New Hampshire community.

\section{E N D N O T E S}

1. R. E. Dahl, "Adolescent Brain Development: A Period of Vulnerabilities and Opportunities." Annals of New York Academy of Science 1021 (2004): 1-22, doi: 10.1196/annals.1308.001, http:// pmbcii.psy.cmu.edu/dahl/Dahl_Adolescent_brain_development.pdf.

2 . The ages for which data are reported may vary from indicator to indicator, depending on the data that were available.

3. U.S. Census Bureau, Population Estimates, 2000-2007, http://www.census.gov/popest/states/asrh/.

4. Kenneth M. Johnson, The Changing Faces of New Hampshire: Recent Demographic Trends in the Granite State. A Carsey Institute Report on New England (Durham, NH: University of New Hampshire, 2007).

5. U.S. Census Bureau, Population Estimates, 2000-2007, http://www.census.gov/popest/states/asrh/. 
6. Ibid. The U.S. Census Bureau defines disability as "a long-lasting physical, mental, or emotional condition ... [that] can make it difficult for a person to do activities such as walking, climbing stairs, dressing, bathing, learning, or remembering. This condition can also impede a person from being able to go outside the home alone or to work at a job or business." http://factfinder.census.gov/home/en/ epss/glossary_a.html.

7. These percentages are based on the number of students with disabilities enrolled in New Hampshire schools so do not include youth with disabilities who may not be in school. It also does not include young adults age 22 to 24 that have disabilities and have aged out of school.

8. National Center for Education Statistics, Digest of Education Statistics: 2008 (Washington, DC: National Center for Education Statistics, March 2009).

9. New Hampshire Department of Education. Reports on State Total Completers by Category, http://www.education.nh.gov/data/ dropouts.htm

10. New Hampshire Department of Education, Reports on Early Exit and Dropout Rates for Grades 9-12, http://www.education. nh.gov/data/dropouts.htm.

11. U.S. Department of Education, Office of Civil Rights, "OCR Elementary and Secondary Survey," U.S. Department of Education National Center for Education Statistics, 2000, 2002, 2004, and 2006, http://nces.ed.gov/surveys/frss/publications/92130/pdf/92130_ survey.pdf and Digest of Education Statistics http://nces.ed.gov/ programs/digest/.

12. Barbara Wauchope, "Student Discipline in New Hampshire Schools," co-publication with the Children's Alliance of New Hampshire (Durham: University of New Hampshire, 2009).

13. Ibid.

14. U.S. Department of Agriculture Food and Nutrition Service, "Characteristics of Supplemental Nutrition Assistance Program Households: Fiscal Year 2008," September 2009, http://www.fns.usda.gov/ ora/menu/Published/SNAP/FILES/Participation/2008Characteristics.pdf.

15. The 2009-2010 data are preliminary, based on counts made in January 2010.

16. U.S. Census Bureau, 2007 American Community Survey Series ACS-01, http://factfinder.census.gov/.

17. Missouri Economic Information and Research Center, Missouri Department of Economic Development, Cost of Living Data Series 4th Quarter 2009, http://www.missourieconomy.org/indicators/ cost_of_living/index.stm.

18. U.S. Census Bureau American Community Survey 1-Year Estimates for 2000-2008, http://factfinder.census.gov/servlet/ DatasetMainPageServlet?_program $=$ ACS\&_submenuId $=$ \&_ lang=en\&_ts=.

19. Barbara Wauchope, "Homeless Youth in New Hampshire" co-publication with the Children's Alliance of New Hampshire (Durham: University of New Hampshire, 2010).

20. New Hampshire RSA 457: 4-9, http://www.gencourt.state.nh.us/ rsa/html/xliii/457/457-mrg.htm.
21. New Hampshire Department of State Division of Vital Records Administration, http://nhvrinweb.sos.nh.gov/Default.aspx.

22. Ibid.

23. Preliminary data from the Centers for Disease Control \& Prevention (CDC) indicates that nationally this increase was temporary and rates are declining again. However, data are not yet available to know if this change has also occurred in New Hampshire. B. E. Hamilton, J. A. Martin, and S. J. Ventura, "Births: Preliminary Data for 2008," National Vital Statistics Report, Vol. 58, No. 16 (April 2010).

24. New Hampshire Department of Health and Human Services, Division of Public Health Services, New Hampshire STD/HIV Surveillance Program Five-Year Data Summary Report 2004-2008.

25. Ibid.

26. Findings from the Youth Risk Behavior Survey reported by the National Center for Disease Prevention and Promotion at the CDC show that the percentage of students in New Hampshire who vomited or took laxatives to lose weight or to keep from gaining weight during the previous thirty days was 3.9 percent in 2009 compared to 4.3 percent nationally in 2007.

27. "Virtual Worlds: The remarkable power of alternate realities, Digital_Nation: Life on the Virtual Frontier," Frontline, Public Broadcasting System, http://www.pbs.org/wgbh/pages/frontline/ digitalnation/virtual-worlds/internet-addiction/.

28. "Interview with Clifford Nass, Digital_Nation: Life on the Virtual Frontier," Frontline, Public Broadcasting System, http://www.pbs. org/wgbh/pages/frontline/digitalnation/interviews/nass.html.

29. J. J. Block, "Issues for DSM-V: Internet Addiction," American Journal of Psychiatry 165 (March 2008): 306-307, doi: 10.1176/appi. ajp.2007.07101556, http://ajp.psychiatryonline.org/cgi/content/ full/165/3/306

30. Centers for Disease Control \& Prevention, National Center for Disease Prevention and Promotion, YRBSS: Youth Risk Behavior Surveillance System, http://www.cdc.gov/HealthyYouth/yrbs/.

31. Ibid.

32. U.S. Drug Enforcement Agency, "New Hampshire 2008” factsheet, March 2008, http://www.justice.gov/dea/pubs/state_ factsheets/newhampshire.html.

33. Centers for Disease Control and Prevention, National Center for Disease Prevention and Promotion, YRBSS: Youth Risk Behavior Surveillance System, http://www.cdc.gov/HealthyYouth/yrbs/.

34. From a draft report by Eric Borrin, New Hampshire Department of Health and Human Services, Division of Juvenile Services.

35. R. E. Dahl, "Adolescent Brain Development: A Period of Vulnerabilities and Opportunities." Annals of New York Academy of Science 1021 (2004): 1-22, doi: 10.1196/annals.1308.001. http:// pmbcii.psy.cmu.edu/dahl/Dahl_Adolescent_brain_development.pdf.

36. U.S. Census Bureau, http://www.census.gov/cgi-bin/saipe/ national.cgi? year=2008\&ascii=\#SA91. 


\section{SOURCES FOR FIGURES}

Fig. 1. U.S. Census Bureau Population Estimates. Annual Estimates of the Resident Population by Age, Sex, Race, and Hispanic Origin for Counties, April 1, 2000 to July 1, 2008, http://www.census.gov/ popest/counties/asrh/CC-EST2008-alldata.html.

Fig. 2. U.S. Census Bureau Population Estimates, http://www.census. gov/popest/states/asrh/files/SC-EST2008-alldata6-MT-PA.csv.

Fig. 3. U.S. Census Bureau American Community Survey 1-Year Estimates for 2000-2008, http://factfinder.census.gov/servlet/ DatasetMainPageServlet?_program=ACS\&_submenuId=\&_ lang=en\&_ts $=$.

Fig. 4. The College Board. College Bound Seniors State Profile Reports: New Hampshire. Reports for 2000-2008, http:// professionals.collegeboard.com/data-reports-research/sat/archived.

Fig. 5. National Center for Education Statistics. Digest of Education Statistics. Reports for 2001-2009, http://nces.ed.gov/pubsearch/ getpubcats.asp?sid=091\#.

Fig. 6. Ibid.

Fig. 7. New Hampshire Department of Education. State Total Completers by Category. Reports for 2000-2001 through 2007-2008, http://www.ed.state.nh.us/education/data/DropoutsAndGraduates.htm.

Fig. 8. U.S. Census Bureau American Community Survey 1-Year Estimates for 2002-2008, http://factfinder.census.gov/servlet/ DatasetMainPageServlet?_program =ACS\&_submenuId $=$ \& lang $=$ en\&_ts $=$.

Fig. 9. Ibid.

Fig. 10. New Hampshire Department of Education. Free/Reduced School Lunch Eligibility Rates by School. Reports for 2004-2005 through 2009-2010, http://www.ed.state.nh.us/education/data/ enrollment.htm.

Fig. 11. U.S. Census Bureau American Community Survey 1-Year Estimates for 2000-2008, http://factfinder.census.gov/servlet/ DatasetMainPageServlet?_program =ACS\&_submenuId $=$ \& lang=en\&_ts $=$.

Fig. 12. Ibid.

Fig. 13. Ibid.

Fig. 14. New Hampshire Department of Education, Division of Instruction.

Fig. 15. Centers for Disease Control and Prevention, http://wonder. cdc.gov/natality.html.

Fig. 16. Centers for Disease Control and Prevention, National Center for Disease Prevention and Promotion, YRBSS: Youth Risk Behavior Surveillance System, http://www.cdc.gov/HealthyYouth/yrbs/.

Fig. 17. New Hampshire Department of Health and Human Services, Division of Public Health Services. New Hampshire STD/ HIV Surveillance Program Five-Year Data Summary Report 20042008, http://www.dhhs.state.nh.us/NR/

Fig. 18. Centers for Disease Control and Prevention, National Center for Disease Prevention and Promotion, YRBSS: Youth Risk Behavior Surveillance System, http://www.cdc.gov/HealthyYouth/yrbs/.
Fig. 19. Substance Abuse and Mental Health Services Administration. National Survey on Drug Use and Health. State Estimates of Substance Use 2002-2003 through 2006-2007, http://www.oas.samhsa.gov/states.htm\#2k2.

Fig. 20. Centers for Disease Control and Prevention, National Center for Disease Prevention and Promotion, YRBSS: Youth Risk Behavior Surveillance System, http://www.cdc.gov/HealthyYouth/yrbs/.

Fig. 21. National Highway Traffic Safety Administration. Fatality Analysis Reporting System Encyclopedia, http://www-fars.nhtsa.dot. gov/Main/index.aspx.

Fig. 22. Substance Abuse and Mental Health Services Administration. National Survey on Drug Use and Health. State Estimates of Substance Use 2002-2003 through 2006-2007, http://www.oas.samhsa.gov/states.htm\#2k2.

Fig. 23. Ibid.

Fig. 24. Ibid.

Fig. 25. Centers for Disease Control and Prevention, National Center for Disease Prevention and Promotion. YRBSS: Youth Risk Behavior Surveillance System, http://www.cdc.gov/HealthyYouth/yrbs/.

Fig. 26. Centers for Disease Control and Prevention, http://wonder. cdc.gov/mortSQL.html.

Fig. 27. Centers for Disease Control and Prevention, National Center for Disease Prevention and Promotion, YRBSS: Youth Risk Behavior Surveillance System, http://www.cdc.gov/HealthyYouth/yrbs/.

Fig. 28. Ibid.

Fig. 29. Ibid.

Fig. 30. Office of Juvenile Justice and Delinquency Prevention. Statistical Briefing Book, http://ojjdp.ncjrs.gov/ojstatbb/crime/faqs.asp\#1.

Fig. 31. Office of Juvenile Justice and Delinquency Prevention. Statistical Briefing Book, http://ojjdp.ncjrs.gov/ojstatbb/corrections/ faqs.asp $\# 2$.

Fig. 32. New Hampshire Department of Corrections. Annual Reports for 2000-2009, http://www.nh.gov/nhdoc/divisions/ publicinformation/index.html.

\section{A C K N O W L E D G M E N T S}

The author would like to thank Ashton Dacey, Americorps VISTA worker for the Children's Alliance of New Hampshire, for her assistance with data for this project. For reading and providing comments on the brief, our thanks go to Tricia Lucas and Aviva Grasso of New Futures and Mil Duncan and Terri Rippett of the Carsey Institute. Special thanks to Ellen Fineberg, president of the Children's Alliance of New Hampshire and our collaborator on this project, for her support and helpful feedback throughout the production of this brief.

\section{ABOUT THE AUTHOR}

Barbara Wauchope is director of evaluation and a research associate professor at the Carsey Institute at the University of New Hampshire (barb.wauchope@unh.edu). 


\section{Children's Alliance of New Hampshire}

\section{Raising Our Voices for Children}

The Children's Alliance of New Hampshire promotes policies and practices that enable all children to lead healthy and productive lives and to reach their full potential.

Children's Alliance of New Hampshire

Two Delta Drive

Concord, NH 03301

(603) 225-2264

Info@childrennh.org

http://www.childrennh.org

\section{rall \\ kids \\ count}

\section{A Project of}

Foundation

"This research was funded in part by the Annie E. Casey Foundation; we thank them for their support. The findings and conclusions presented in this report are those of the Carsey Institute and do not necessarily reflect the opinions of the foundation."

\section{$\triangle$ UNIVERSITY Ai. of NEW HAMPSHIRE}

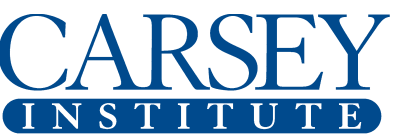

Building knowledge for families and communities

The Carsey Institute conducts policy research on vulnerable children, youth, and families and on sustainable community development. We give policy makers and practitioners timely, independent resources to effect change in their communities.

This work was supported, in part, by the Annie E. Casey Foundation for Kid's Count.

Huddleston Hall

73 Main Street

Durham, NH 03824

(603) 862-2821

www.carseyinstitute.unh.edu 